\title{
Fruit and Vegetable Purchases in Farmer's Market Stands: Analysing Survey and Sales Data
}

\author{
Pauline Rebouillat ${ }^{1,2} \mathbb{D}$, Sarah Bonin ${ }^{3}$, Yan Kestens ${ }^{2,3}{ }^{\mathbb{D}}$, Sarah Chaput ${ }^{2,3}$, Louis Drouin ${ }^{4}$ and \\ Geneviève Mercille 5,6,*(D) \\ 1 Institut de Santé Publique d'Épidémiologie et de Développement (ISPED), Université de Bordeaux, \\ 33000 Bordeaux, France; p.rebouillat@outlook.com \\ 2 Centre de recherche du Centre hospitalier de l'Université de Montréal, 850 St-Denis, Montréal, QC H2X 0A9, \\ Canada; yan.kestens@umontreal.ca (Y.K.); sarah.chaput@umontreal.ca (S.C.) \\ 3 Département de médecine sociale et préventive, École de Santé Publique de l'Université de Montréal, \\ 7101 Avenue du Parc, Montréal, QC H3N 1X9, Canada; sarah.bonin@umontreal.ca \\ 4 Direction régionale de santé publique, Centre intégré universitaire de santé et services sociaux du \\ Centre-Sud-de-l'Ile-de-Montréal, Montréal, QC H2L 1M3, Canada; louis.drouin.ccsmtl@ssss.gouv.qc.ca \\ 5 Département de nutrition, Université de Montréal, 2450 Chemin de la Côte-Sainte-Catherine, Montréal, \\ QC H3T 1A8, Canada \\ 6 Centre de recherche en santé publique, 1301 Sherbrooke Est, Montréal, QC H2L 1M3, Canada \\ * Correspondence: genevieve.mercille.1@umontreal.ca
}

Received: 2 November 2019; Accepted: 15 December 2019; Published: 21 December 2019

\begin{abstract}
Farmers' market implementation holds promise for increasing access to healthy foods. Although rarely measured, purchase data constitute an intermediate outcome between food environment and actual consumption. In a study conducted with two seasonal Fruits and Vegetables (FV) stands in a disadvantaged area of Montréal (Canada), we analysed how accessibility, perception, and mobility-related factors were associated with FV purchase. This analysis uses a novel measure of FV purchasing practices based on sales data obtained from a mobile application. A 2016 survey collected information on markets' physical access, perceived access to FV in the neighbourhood, usual FV consumption and purchases. Multivariate models were used to analyse three purchasing practice indicators: number of FV portions, FV variety and expenditures. Average shoppers purchased 12 FV portions of three distinct varieties and spent $5 \$$. Shoppers stopping at the market on their usual travel route spent less $(p=0.11)$, bought fewer portions $(p=0.03)$ and a lesser FV variety $(p<0.01)$. FV stands may complement FV dietary intake. Individuals for whom the market is on their usual travel route might make more frequent visits and, therefore, smaller purchases. The novel data collection method allowed analysis of multiple purchase variables, is precise and easy to apply at unconventional points of sales and could be transposed elsewhere.
\end{abstract}

Keywords: fruits and vegetables; food access; food environment; farmers' market; health inequalities; sales data; food purchases; disadvantaged neighbourhoods

\section{Introduction}

Disadvantaged populations are more heavily affected by non-communicable disease in Canada and in other industrialized countries [1-3]. They also consume fewer fruits and vegetables (FV) [4,5], which is associated with non-communicable diseases such as obesity [6]. They may also be more dependent on their immediate surroundings and on public transit for food supplies [7-13], due to limited financial and material resources (e.g., access to a car). Promising strategies to increase access to FV in disadvantaged neighbourhoods with poor access to healthy foods include opening farmers' markets, or at a smaller scale, FV stands and mobile vendors [14]. Furthermore, those initiatives 
are promoted by sustainable food system coalitions in major Canadian cities such as Montreal [15], Edmonton [16] and Toronto [17]. Freshness, variety, quality and taste are important attributes of these alternative food supplies that may help FV consumption [18-23]. However, evidence on their effectiveness in increasing FV access remains scarce [24,25].

Determinants of individuals' use of farmers' markets are similar to those related to other food acquisition practices and include price, location, consumer perceptions of food offer and consumer values [11,12,22,23,26-31]. For low-income shoppers, access considerations (e.g., location, accessibility, price and opening hours) stand out as key factors governing farmers' market use [28,30,32]. Several studies on farmers' market interventions designed to improve FV accessibility in Canada and elsewhere report sociodemographic determinants of use. While shoppers are primarily middle-aged women [20,21,33-37], associations between educational attainment or ethnicity and shopping patterns are discordant [38]. Market location appears to be linked to customers' socioeconomic profiles [35,39]. For example, the relocation of an established farmers' market near a bus terminal led not only to an increase in overall attendance, but also to a diversification of the customer base, attracting more men, youth and individuals from food deserts and low-income neighbourhoods [35]. Upon relocating, the market also experienced a significant increase in the proportion of its customers that use public transit or active transportation.

Most intervention studies use FV intake as a main outcome for evaluating the effectiveness of farmers' markets $[23,24,33,34,40-50]$. However, the majority of these studies are based in the United States, where government assistance programs are used as financial incentives for purchasing FV. This limits our ability to differentiate the effects of market use per se from those of the incentive programs, reducing the transferability of findings to other contexts [24]. A few studies conducted either in the USA or in other countries considered a broader population that did not have access to such incentives [34,39,42,51-55]. Those that focus on farmers' market interventions without financial incentives report an increase in FV intake [34,55], including certain types of FV [42,53] or a perceived increase in intake $[34,39,51,52,54]$. Study designs include a longitudinal pre-post study [42], a mixed-method cohort study [55], a repeated cross-sectional study [34], two cross-sectional studies [51,52], a case study [39] and a one-group post-intervention study [54].

Although rarely measured, assessing purchases is relevant for evaluating intervention implementation and effectiveness for increasing FV consumption given that purchases constitute an important intermediate variable between the food environment and actual consumption. Collecting purchase data at Unconventional Points of Sales (UPS) such as farmers' markets and corner stores is a challenge [56] because existing databases using barcodes (e.g., Nielsen) are generally limited to purchases made in supermarkets and other stores equipped with scanning systems [57,58]. Only five identified farmers' market studies measured food purchases $[43,46,56,59,60]$. These studies collected data through self-report or by manually recording purchase inventories. However, these two methods impose a heavy burden on both researchers and participants $[43,46,56,59,60]$. Other farmers' market studies analyse self-reported use of government incentive programs, government incentive sales data or records of coupon redemption [61-66], self-reported amounts spent [67] or total sales [39]. Some studies on convenience stores use purchase data collected using these same methods [68-75]. Given technological advances and changing legal requirements [76] in tracking sales, point of sales (POS) terminals are starting to gain popularity in UPS. They also represent interesting new purchasing data sources. To date, one study has used POS daily sales data aggregated by product category [77].

In the present study conducted among shoppers of two seasonal FV stands in a disadvantaged area of Montréal (Canada) with low FV access, we analysed factors associated with FV purchases, namely, accessibility measurements, individual perceptions of food access and other mobility-related factors. To do so, we developed and tested a novel method for measuring FV purchases based on sales data collected through a mobile POS application. The three derived purchase indicators are the number of FV portions, the variety of FV purchased, and the amount spent per purchase. 


\section{Materials and Methods}

\subsection{Intervention Context and Description}

With 1.8 million inhabitants, Montreal ranks as the second-largest city in Canada. The prevalence of poverty and food insecurity are concerning, with $21 \%$ of inhabitants living under the low-income threshold [78] and 12.7\% of households reported as food insecure as of 2014 [79]. Half the adult population is overweight and one-third has a chronic disease, while only $40 \%$ eat the recommended number of daily servings of FV [80]. Differential access to healthy food is an important health equity issue and has been the target of research over the last 15 years [81-83]. Although food deserts per se are not common in Montreal [81], it is estimated that one-third of low-income citizens have poor access to fresh FV within walking distance from their home [84]. Public health programs and policy makers increasingly promote farmers' markets as a viable source of fresh FV, especially in low-income, urban settings $[85,86]$. The two FV stands assessed in this study were run by a not-for-profit organization, YQQ (Y'a QuelQu'un l'aut bord du mur), and are among the many interventions tackling local population's physical and economic access to FV funded by the Montreal Public Health Department since 2008.

Both FV stands were located in the Mercier-Hochelaga-Maisonneuve district of Montréal, $1.7 \mathrm{~km}$ apart from each other. One was located along a transit route next to a subway station and had two adjacent neighbourhoods, Louis-Riel and Longue-Pointe (Cadillac market). The other was located near a leisure center in Guybourg, a neighbourhood considered as a landlocked food desert (Guybourg market). In these three neighbourhoods, respectively, $16.6 \%, 20.3 \%$ and $20.1 \%$ of adults lived under the low-income measure (LIM) [87], meaning they earned less than half of the median household income adjusted for household size [88]. Moreover, respectively, 31\%, 23\% and 100\% of the low-income population had low physical access $\left(<215 \mathrm{ft}^{2} \mathrm{FV}\right.$ surface) to fresh FV within walking distance $(500 \mathrm{~m})$ from their homes [89].

The Cadillac market first opened on 7 September 2016 and closed its doors on October 28th that same season, for a total of 14 days of operation. Its operating hours were from 13:00 or 14:00 to 18:00 or 19:00. First introduced in 2014 [90], the Guybourg market was also open three days per week, from 7 July to 29 October 2016, from 15:00 to 19:00 on weekdays and from 10:00 to 14:00 on Saturday, resulting in 45 days of operation. With an average of 53 shoppers/day, customer traffic at Cadillac market was much higher than at Guybourg market (16 shoppers/day) [91]. In both FV stands, all purchases were recorded by vendors using the Square Point of Sale application (Square, San Francisco, CA, USA). Users could pay by cash or credit card.

\subsection{Design and Sampling}

A face-to-face on-site survey was conducted among a convenience sample of adult shoppers buying fruits and vegetables, from 21 September to 28 October 2016. Even though Cadillac opened later in the season (Sept-Oct), data at both markets were collected during the same period to control for seasonal variation in FV offer. For both markets, two research assistants were present at all times during the opening hours, except for when the markets were open simultaneously (once a week). In that case, Cadillac market was preferred for data collection due to higher traffic. For both sites, the research assistants interviewed shoppers just after they completed their purchases. Eligibility criteria included being 18 years or older, speaking French or English, having lived in one's current home since at least 1 July 2016 and not having already completed the survey. If respondents lacked time, the research assistants collected their phone number for a phone interview at their preferred time and noted the time and date of their purchase. Of 326 eligible shoppers approached at Cadillac market, 68\% completed the on-site survey ( $\mathrm{n}=218$, including 43 participants by follow-up phone calls). In Guybourg, 101 eligible shoppers were approached, and $65 \%$ completed the on-site survey $(n=66$, including 6 by phone). All participants were asked to give their verbal consent by the interviewers using a script approved by the Ethics Committee of the Centre Hospitalier de l'Université de Montréal (CHUM) in August 2016 (N.D. 16.128). A more in-depth description of the sampling can be found in Chaput et al. [92]. 


\subsection{Measures}

Research assistants administered a 38-item questionnaire to shoppers, taking, on average, eight minutes to complete. Questions were extracted or adapted from previous studies [52,93-98]. Prior to data collection, the questionnaire was reviewed by the project partners and pre-tested with 9 participants by a research assistant in French and English. A description of the variables can be found in Chaput et al. [92], except for the FV purchase method and indicators that will be fully described below. Briefly, sociodemographic characteristics included age, sex, ethnicity, household income category (before taxes and deduction), household main source of income and education level. FV intake was assessed using the 6-item FV module of the Short Diet Questionnaire, previously validated among a French-speaking population [97]. Perceived access to FV in the neighbourhood was measured by assessing participants' level of agreement to four statements regarding dimensions of perceived access: availability, physical access and affordability (see Table 1). Participants' market shopping habits (in markets other than the intervention markets) were reported in times per week or month and used as control variables.

Table 1. Descriptive analyses of participants recruited in the intervention markets $(n=257)$.

\begin{tabular}{|c|c|}
\hline Variables & Total Sample $(n=257)$ \\
\hline \multicolumn{2}{|l|}{ Sociodemographic characteristics } \\
\hline \multicolumn{2}{|l|}{ Age, years $(\%)$} \\
\hline $18-44$ & 47.9 \\
\hline $45-64$ & 36.6 \\
\hline 65 and over & 15.6 \\
\hline \multicolumn{2}{|l|}{$\operatorname{Sex}(\%)$} \\
\hline Male & 77.8 \\
\hline Female & 21.8 \\
\hline Missing & 0.39 \\
\hline Household size (mean, SD) & $2.2(1.2)$ \\
\hline \multicolumn{2}{|l|}{ Household categories (person/household) } \\
\hline 1 & 34.6 \\
\hline 2 & 32.7 \\
\hline 3 & 15.6 \\
\hline More than 3 & 17.1 \\
\hline \multicolumn{2}{|l|}{ Education (\%) } \\
\hline High school or less & 24.1 \\
\hline Trade school or pre-university college & 37.4 \\
\hline University & 38.5 \\
\hline \multicolumn{2}{|l|}{ Household under the LIM (\%) } \\
\hline Yes & 23.0 \\
\hline No & 61.9 \\
\hline Missing & 15.2 \\
\hline \multicolumn{2}{|l|}{ Born in Canada (\%) } \\
\hline Yes & 78.2 \\
\hline No & 21.8 \\
\hline \multicolumn{2}{|l|}{ Spatial and mobility-related variables } \\
\hline \multicolumn{2}{|l|}{ Car access $(\%)$} \\
\hline Yes & 55.6 \\
\hline No & 44.4 \\
\hline Home-to-market distance, meters & $1992.9(3590.5)$ \\
\hline
\end{tabular}


Table 1. Cont.

\begin{tabular}{|c|c|}
\hline Variables & Total Sample $(n=257)$ \\
\hline \multicolumn{2}{|l|}{ Residing $\leq 1 \mathrm{~km}$ from the market $(\%)$} \\
\hline Yes & 66.2 \\
\hline Unhealthy/healthy densities ratio (mean, SD) & $2.8(0.6)$ \\
\hline \multicolumn{2}{|l|}{ Market on usual travel route $(\%)$} \\
\hline Yes & 77.8 \\
\hline No & 21.4 \\
\hline Missing & 0.8 \\
\hline \multicolumn{2}{|l|}{ FV consumption, perceived access and shopping habits } \\
\hline FV consumption per day (mean, SD) ( $0.8 \%$ missing values) & $4.6(2.1)$ \\
\hline \multicolumn{2}{|l|}{ Eating at least $5 \mathrm{FV}$ per day, \% } \\
\hline Yes & 41.6 \\
\hline \multicolumn{2}{|l|}{$\begin{array}{l}\text { Easy to find fresh FV of good quality in own } \\
\text { neighbourhood (\%) }\end{array}$} \\
\hline Agree & 47.1 \\
\hline More or less agree & 15.2 \\
\hline Disagree & 37.0 \\
\hline Missing & 0.8 \\
\hline \multicolumn{2}{|l|}{ Fresh FV are not affordable in own neighbourhood (\%) } \\
\hline Agree & 28.4 \\
\hline More or less agree & 14.8 \\
\hline Disagree & 52.9 \\
\hline Missing & 3.9 \\
\hline \multicolumn{2}{|l|}{ Market shopping habits (\%) } \\
\hline Less than once a month & 22.6 \\
\hline 1 to 3 times/month & 25.6 \\
\hline Once a week or more & 49.8 \\
\hline Missing & 2.0 \\
\hline \multicolumn{2}{|l|}{ Number of visits at the intervention market (\%) } \\
\hline One visit & 58.4 \\
\hline Between one visit total and one visit per month & 29.6 \\
\hline More than one visit per month & 12.06 \\
\hline \multicolumn{2}{|l|}{ Purchasing practice analysis } \\
\hline Number of FV portions purchased, mean (SD) & $11.7(13.8)$ \\
\hline Variety of FV purchased, mean (SD) & $2.8(2.0)$ \\
\hline \multicolumn{2}{|l|}{ Amount spent (CAD), } \\
\hline mean (SD) & $5.0(3.9)$ \\
\hline Median & 4.1 \\
\hline
\end{tabular}

NB: No missing values when the Missing category is not mentioned. LIM: Low-income measure; FV: fruits and vegetables/SD: Standard Deviation.

Spatial- and mobility-related variables such as if the intervention market was along the usual travel route (yes/no), the home address and car access (yes/no) were obtained from the questionnaire. Residential exposure to the retail food environment was computed as a relative measure of unhealthy to healthy outlets [99]. Specifically, we calculated the ratio of the sum of densities of unhealthy stores to the sum of densities of healthy stores, from 2010 Enhanced Point-Of-Interest database (DMTI Spatial ${ }^{\circledR}$, ON, Canada) using ArcGIS v10.3 (Esri, CA, USA). For each food outlet category, kernel densities with an adaptive bandwidth of $1 \%$ were calculated within a $500 \mathrm{~m}$ road network buffer of participants' homes. The term "healthy" restrictively referred to "outlets that allow for complete meals 
with fruit and vegetable options", and included supermarkets, fruit and vegetable stores, natural food stores, and grocery stores. Inversely, "outlets allowing for complete meals but offering few or no fruit and vegetable options" (i.e., convenience stores and fast-food restaurants) were termed "unhealthy" (see Clary et al. article for more details [99]).

Details of participants' purchases were collected using the POS application Square that was used as a cash register by the vendor. At both markets, sellers entered all purchased products with the corresponding quantity (number of units or weight) directly on the payment platform to calculate the total amount of the transaction. Customers had the option of receiving the invoice by e-mail. The payment platform assigned a unique alphanumeric character string to each transaction that was automatically recorded in an MS Excel format database. We gained access to this database through our partnership with YQQ. The database did not contain any personal or banking information. The first 4 characters of the transaction code (created by the Square application) were used as a unique customer identifier. In order to retrieve respondents' complete transaction details in the database, the research assistants noted the time and date of the purchase and proceeded to a brief verification of the items purchased. The research assistants used strategies to facilitate the retrieval of the right transaction, such as (1) noting the least popular items rather than the most popular items purchased, and (2) entering the quantity purchased for very popular items (e.g., 6 vs. 12 ears of corn). In the case where a respondent completed two transactions (e.g., forgot to buy something), the details were collected for both transactions by the research assistants, but treated as a unique purchase.

\section{Dependent Variables}

Three FV purchase indicators were computed from the database and considered dependent variables of the study: number of FV portions purchased, variety of FV purchased and amount spent. Specific manipulations were needed to calculate the first two indicators, as described below.

Fresh FV were sold by weight or by unit. For FV sold by unit, ten items of each species were weighed by a research assistant in order to establish an average weight for one unit sold at these points of sales. For some vegetables, less than 10 items were available for measurement. In this case, the experimental average was compared with the average weight indicated in the Canadian Nutrient File [100]. When the quantity of a given purchased vegetable was missing for one participant, it was replaced by the average quantity of this vegetable purchased by other participants in the sample.

The percentage of edible portion was determined for each species of FV according to the Canadian Nutrient File. For each species of FV, we calculated the weight corresponding to one serving of FV as recommended in the 2007 Canadian Food Guide.

We computed the number of FV portions for each species of FV purchased according to the formula below, and then summed all items to obtain the shoppers' total portions of FV in their basket:

$$
\text { Number of FV portions purchased/item }=\frac{\text { quantity }(\text { grams }) \times \% \text { ofedible portion }}{\text { weight of one portion }}
$$

The variety of purchased FV was computed according to the number of different fruit and vegetable species purchased, herbs and home-made vegetable preparations (e.g., tomato sauce, relish). Different products were counted as one species if their nutritional compositions were similar; for example, all types of apple were grouped together, but cherry tomatoes were counted separately from all other types of tomatoes, as were red and yellow onions, and green and yellow zucchinis.

The amount spent per transaction in Canadian dollars was extracted directly from the Square database and corrected to remove any non-edible items that may have been purchased (i.e., bag, returnable jar).

\subsection{Statistical Analysis}

Multivariate models were run to analyse factors associated with FV purchases. 
All variables in Table 1 were tested for inclusion (except Residing $<1 \mathrm{~km}$ of market) using univariate models $(p<0.20)$. All models were adjusted for sociodemographic variables (age, gender, household size, ethnicity, household revenue under the LIM, education). Additional adjustments were made to FV consumption, market shopping habits, number of visits at the intervention market and to the market location. Mobility variables such as car access, home-to-market distance and density ratio were forced into the models. A multivariate linear regression model was used to analyse the number of FV portions purchased. The dependent variable was transformed by taking the square root in order to fit the linear regression assumptions. Analysis of the amount spent was performed using a linear regression model (without transformation). Linearity in the logit of the dependent variables was evaluated using the Box-Tidwell procedure [93]. Given the distribution of the FV variety variable, a Poisson regression model was used. As over-dispersion is a common issue in Poisson regression models, it was checked for using Pearson's chi-square ratio.

First, the Multiple Imputation by Chained Equations procedure ( $R$ package 'mice') was used to handle missing values. Missing values were observed mostly for household income $(15.2 \%$, $n=39)$, market shopping habits $(2.0 \%, n=5)$, and perceived affordability of FV in the neighbourhood $(3.9 \%, n=10)$. A total of 27 observations were excluded because of incoherent and non-imputable geographic information (postal code), leaving 257 participants for these analyses. Five imputed datasets were generated and then pooled. The imputation method was defined according to variable type. All variables considered in each model were included in the multiple imputation procedure. The household main source of income was added as a predictor in the multiple imputation models.

Descriptive and bivariate statistics were conducted using SAS 9.2 statistical software and multiple imputation performed using R (3.5.1) package 'mice'. The level of significance was set at $\alpha=0.05$.

\section{Results}

\subsection{Descriptive Statistics}

Table 1 describes the characteristics of the whole sample. Shoppers were mostly women, born in Canada, between 18 and 44 years old, with completed postsecondary education. Nearly a quarter of the respondents were under the low-income measure, which is slightly higher than in the studied neighbourhoods ( $16.6 \%$ to $20.3 \%$ ). The main source of income was salary or self-employment.

Regarding spatial and mobility variables, slightly more than half of the shoppers had access to a car and two-thirds resided $\leq 1 \mathrm{~km}$ from their market. The market was located on the usual travel routes of most participants $(77.8 \%)$.

Forty-two percent of shoppers ate less than $5 \mathrm{FV}$ a day, with an average of 4.6 portions of FV per day. Shoppers' perceptions of FV affordability in their neighbourhood were split between positive opinions and negative/mixed opinions. In the two neighbourhoods, $34.2 \%$ and $30.7 \%$ of shoppers reported not having easy access to fresh FV within walking distance from their homes or on their usual travel route. Twenty-two percent were infrequent market shoppers (less than once a month).

On average, shoppers purchased nearly 12 portions of $\mathrm{FV}$ and three distinct varieties of $\mathrm{FV}$, and spent $5 \$$ per transaction.

\subsection{Factors Associated with FV Purchasing Practices}

Tables 2-4 show results of the multivariate regression models used to analyse purchasing practices in the two markets, respectively, the number of FV portions purchased, the amount spent and the variety of FV purchased. 
Table 2. Results for multivariate linear regression modeling of number of FV portions purchased ( $n=257)$.

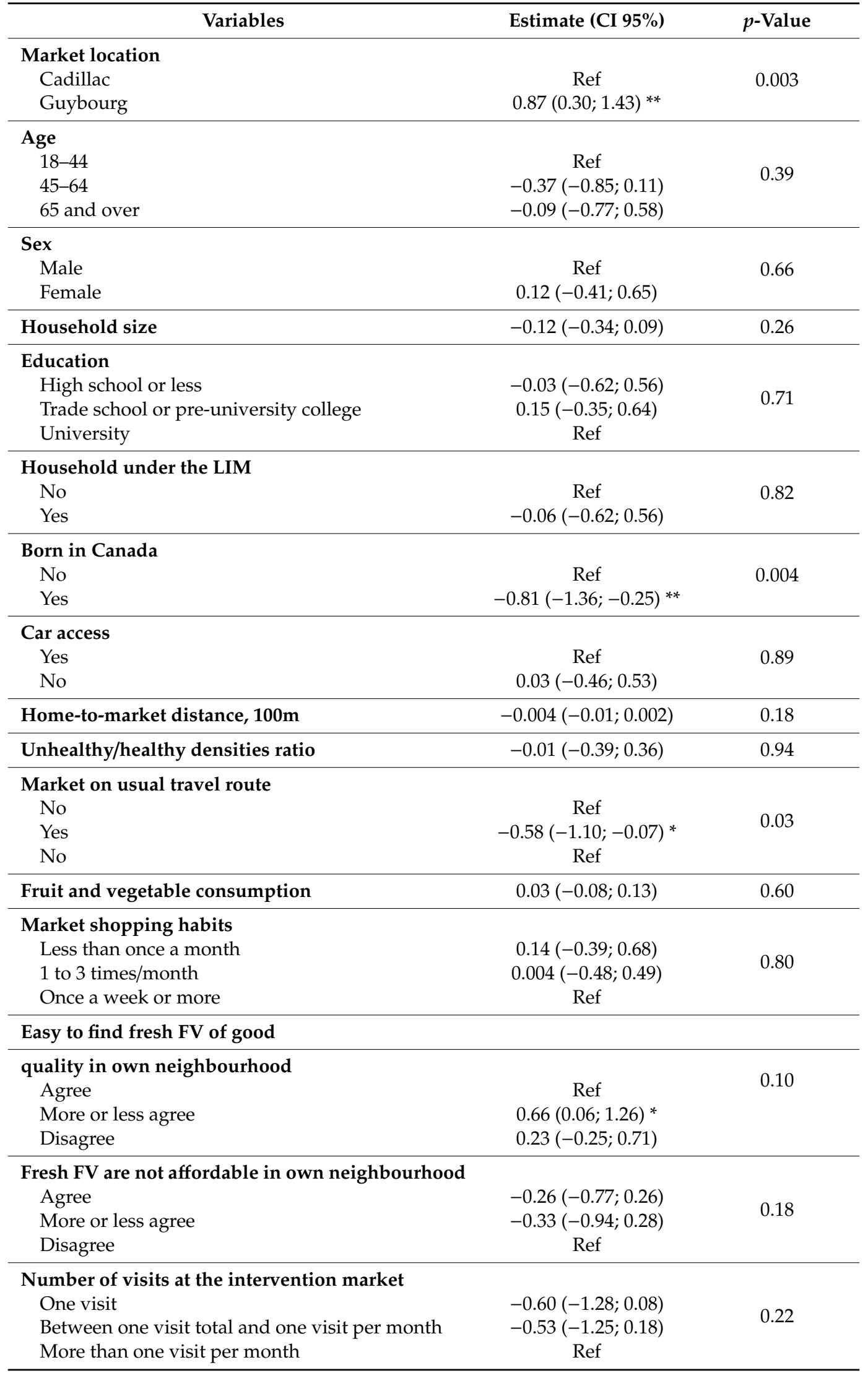


Table 3. Results from multivariate linear regression modeling of amount spent $(n=257)$.

\begin{tabular}{|c|c|c|}
\hline Variables & Estimate (CI 95\%) & $p$-Value \\
\hline $\begin{array}{l}\text { Market location } \\
\text { Cadillac } \\
\text { Guybourg }\end{array}$ & $\begin{array}{c}\text { Ref } \\
-0.01(-1.35 ; 1.32)\end{array}$ & 0.99 \\
\hline $\begin{array}{l}\text { Age, years } \\
\text { 18-44 } \\
45-64 \\
65 \text { and over }\end{array}$ & $\begin{array}{c}\text { Ref } \\
-0.66(-1.80 ; 0.48) \\
-1.15(-2.76 ; 0.46)\end{array}$ & 0.48 \\
\hline $\begin{array}{l}\text { Sex } \\
\quad \text { Male } \\
\text { Female }\end{array}$ & $\begin{array}{c}\text { Ref } \\
0.01(-1.24 ; 1.25)\end{array}$ & 0.99 \\
\hline Household size & $-0.26(-0.77 ; 0.24)$ & 0.31 \\
\hline $\begin{array}{l}\text { Education } \\
\text { High school or less } \\
\text { Trade school or pre-university college } \\
\text { University }\end{array}$ & $\begin{array}{l}0.25(-1.17 ; 1.68) \\
0.37(-0.80 ; 1.54) \\
\quad \operatorname{Ref}\end{array}$ & 0.92 \\
\hline $\begin{array}{l}\text { Household under the LIM } \\
\text { No } \\
\text { Yes }\end{array}$ & $\begin{array}{c}\text { Ref } \\
-0.57(-1.85 ; 0.70)\end{array}$ & 0.37 \\
\hline $\begin{array}{l}\text { Born in Canada } \\
\text { No } \\
\text { Yes }\end{array}$ & $\begin{array}{c}\text { Ref } \\
-1.39(-2.69 ;-0.08) *\end{array}$ & 0.04 \\
\hline $\begin{array}{l}\text { Car access } \\
\text { Yes } \\
\text { No }\end{array}$ & $\begin{array}{c}\text { Ref } \\
-0.33(-1.50 ; 0.85)\end{array}$ & 0.58 \\
\hline Home-to-market distance, $100 \mathrm{~m}$ & $-0.01(-0.02 ; 0.01)$ & 0.22 \\
\hline Unhealthy/healthy densities ratio & $-0.32(-1.19 ; 0.55)$ & 0.47 \\
\hline $\begin{array}{l}\text { Market on usual travel route } \\
\text { No } \\
\text { Yes }\end{array}$ & $\begin{array}{c}\text { Ref } \\
-0.99(-2.21 ; 0.22)\end{array}$ & 0.11 \\
\hline Fruit and vegetable consumption & $0.17(-0.08 ; 0.42)$ & 0.18 \\
\hline $\begin{array}{l}\text { Market shopping habits } \\
\text { Less than once a month } \\
1 \text { to } 3 \text { times/month } \\
\text { Once a week or more }\end{array}$ & $\begin{array}{l}0.12(-1.13 ; 1.38) \\
-0.77(-1.94 ; 0.39) \\
\quad \operatorname{Ref}\end{array}$ & 0.18 \\
\hline $\begin{array}{l}\text { Easy to purchase fresh FV on usual travel route } \\
\text { Agree } \\
\text { More or less agree } \\
\text { Disagree }\end{array}$ & $\begin{array}{c}\text { Ref } \\
-2.21(-4.85 ; 0.42) \\
0.39(-0.70 ; 1.49)\end{array}$ & 0.16 \\
\hline $\begin{array}{l}\text { Fresh FV are not affordable in own neighbourhoo } \\
\text { Agree } \\
\text { More or less agree } \\
\text { Disagree }\end{array}$ & $\begin{array}{l}-0.40(-1.62 ; 0.83) \\
-1.07(-2.49 ; 0.35) \\
\quad \operatorname{Ref}\end{array}$ & 0.20 \\
\hline $\begin{array}{l}\text { Number of visits at the intervention market } \\
\text { One visit } \\
\text { Between one visit total and one visit per month } \\
\text { More than one visit per month }\end{array}$ & $\begin{array}{l}-2.41(-4.02 ;-0.81) * * \\
-1.78(-3.47 ;-0.10) * \\
\quad \operatorname{Ref}\end{array}$ & 0.01 \\
\hline
\end{tabular}


Table 4. Results of Poisson regression modeling of variety of FV purchased $(n=257)$.

\begin{tabular}{|c|c|c|}
\hline Variables & Estimate (CI 95\%) & $p$-Value \\
\hline $\begin{array}{l}\text { Market location } \\
\text { Cadillac } \\
\text { Guybourg }\end{array}$ & $\begin{array}{c}\text { Ref } \\
0.07(-0.13 ; 0.28)\end{array}$ & 0.49 \\
\hline $\begin{array}{l}\text { Age } \\
\qquad 18-44 \\
45-64 \\
65 \text { and over }\end{array}$ & $\begin{array}{c}\text { Ref } \\
-0.10(-0.28 ; 0.08) \\
-0.13(-0.39 ; 0.12)\end{array}$ & $\begin{array}{l}0.28 \\
0.30\end{array}$ \\
\hline $\begin{array}{l}\text { Sex } \\
\quad \text { Male } \\
\text { Female }\end{array}$ & $\begin{array}{c}\text { Ref } \\
0.07(-0.13 ; 0.28)\end{array}$ & 0.47 \\
\hline Household size & $-0.10(-0.17 ;-0.01) *$ & 0.02 \\
\hline $\begin{array}{l}\text { Education } \\
\text { High school or less } \\
\text { Trade school or pre-university college } \\
\text { University }\end{array}$ & $\begin{array}{l}0.05(-0,18 ; 0,28) \\
0.15(-0,04 ; 0,33) \\
\text { Ref }\end{array}$ & $\begin{array}{l}0.68 \\
0.12\end{array}$ \\
\hline $\begin{array}{l}\text { Household under the LIM } \\
\text { No } \\
\text { Yes }\end{array}$ & $\begin{array}{c}\text { Ref } \\
-0.10(-0.32 ; 0.11)\end{array}$ & 0.35 \\
\hline $\begin{array}{l}\text { Born in Canada } \\
\text { No } \\
\text { Yes }\end{array}$ & $\begin{array}{c}\text { Ref } \\
-0.24(-0.44 ;-0.03) *\end{array}$ & 0.02 \\
\hline $\begin{array}{l}\text { Car access } \\
\text { Yes } \\
\text { No }\end{array}$ & $\begin{array}{c}\text { Ref } \\
-0.08(-0.27 ; 0.11)\end{array}$ & 0.39 \\
\hline Home-to-market distance, $100 \mathrm{~m}$ & $-0.001(-0.004 ; 0.001)$ & 0.29 \\
\hline Unhealthy/healthy densities ratio & $0.04(-0.11 ; 0.19)$ & 0.59 \\
\hline $\begin{array}{l}\text { Market on usual travel route } \\
\text { No } \\
\text { Yes }\end{array}$ & $\begin{array}{c}\text { Ref } \\
-0.25(-0.43 ;-0.07) \text { * }\end{array}$ & $<0.01$ \\
\hline Fruit and vegetable consumption & $0.04(0.001 ; 0.08) *$ & 0.04 \\
\hline $\begin{array}{l}\text { Market shopping habits } \\
\text { Less than once a month } \\
1 \text { to } 3 \text { times/month } \\
\text { Once a week or more }\end{array}$ & $\begin{array}{l}0.09(-0.11 ; 0.29) \\
-0.05(-0.25 ; 0.15) \\
\operatorname{Ref}\end{array}$ & $\begin{array}{l}0.39 \\
0.63\end{array}$ \\
\hline Easy to purchase fresh FV on usual travel route & & \\
\hline Agree & Ref & \\
\hline More or less agree & $-0.70(-1.28 ;-0.12) *$ & 0.02 \\
\hline Disagree & $0.03(-0.14 ; 0.20)$ & 0.72 \\
\hline $\begin{array}{l}\text { Fresh FV are not affordable in own neighbourhoo } \\
\text { Agree } \\
\text { More or less agree } \\
\text { Disagree }\end{array}$ & $\begin{array}{l}-0.12(-0.31 ; 0.08) \\
-0.27(-0.52 ;-0.02) * \\
\operatorname{Ref}\end{array}$ & $\begin{array}{l}0.23 \\
0.04\end{array}$ \\
\hline $\begin{array}{l}\text { Number of visits at the intervention market } \\
\text { One visit } \\
\text { Between one visit total and one visit per month } \\
\text { More than one visit per month }\end{array}$ & $\begin{array}{l}-0.34(-0.57 ;-0.11)^{* *} \\
-0.33(-0.58 ;-0.08) * * \\
\text { Ref }\end{array}$ & 0.004 \\
\hline
\end{tabular}




\subsubsection{Sociodemographic Variables}

Attending Guybourg market was significantly associated with a higher number of FV portions purchased ( $\beta=0.87, p=0.003$ ), but not with the variety of FV purchased or the amount spent. Shoppers born in Canada bought cheaper baskets ( $\$ 1.50$ CAD less, $p=0.04)$, with fewer FV portions $(\beta=-0.81$, $p=0.004)$ and a lesser variety of FV $(\beta=-0.24, p=0.02)$. A lower variety of FV purchased was also associated with a larger household size $(\beta=-0.10, p=0.02)$. Other sociodemographic variables such as income or education level were not significantly associated with purchase variables.

\subsubsection{Spatial- and Mobility-Related Variables}

When the market was located on their usual travel route, shoppers spent one dollar less $(p=0.11)$, bought fewer portions $(p=0.03)$ and a lower variety of FV $(\beta=-0.25, p=<0.01)$. Having access to a car, distance between the market and home and residential exposure to the retail food environment were not associated with FV purchases.

\subsubsection{FV Consumption, Perceived Access and Shopping Habits}

FV consumption level was not associated with the number of FV portions purchased nor with the amount spent. Results revealed a weak association between FV consumption level and the variety of FV purchased $(0.04 ; p=0.04)$. No clear tendency was observed for perceptions of FV affordability or ease of finding good quality FV in the neighbourhood.

The amount spent was on average $\$ 2.50$ CAD lower for the shoppers who came only once to the intervention market compared to shoppers who came more than once a month. The number of visits was also significantly and negatively associated with $\mathrm{FV}$ variety $(\beta=-0.34, p=0.009)$.

\section{Discussion}

This study conducted in low-income neighbourhoods of Montreal (Canada) is among the first to analyse FV purchases among urban shoppers in FV stands. It also uses an innovative method for measuring purchases that could be applied to other contexts. Unconventional Points of Sales (UPS) are part of the foodscape in Canada and in other countries and it is important to include them in studies addressing the food environment. However, studies examining food purchases are mostly limited to existing databases using barcodes or self-reporting, thus limiting our possibility of a comprehensive understanding of food purchasing practices including UPS. As more and more interventions implementing UPS are developed, it is important to elaborate reliable tools for monitoring, comparison and evaluation.

Both FV stands studied were located in low-income neighbourhoods with low FV access; one along a transit hub (Cadillac) and the other in a landlocked food desert (Guybourg). While results detected no difference between the two FV stands with respect to variety purchased, amount spent, or FV species offered, they showed that shopping at Guybourg market was associated with a higher number of FV portions purchased. One explanation could be that Guybourg shoppers made cost-saving FV choices (eg., more potatoes and squash; data not shown). Another plausible explanation could be that a higher proportion of Guybourg shoppers had access to a car ( $87.5 \%$ vs. $46.8 \%$, cf. Appendix A Table A1), which facilitated the transportation of larger amounts of food and heavier foods. Guybourg neighbourhood is surrounded by non-residential buildings and has poor public transport service, meaning that car access greatly facilitates travel within and outside the neighbourhood. This explanation would suggest that physical accessibility does affect FV purchasing habits at this particular market by facilitating the purchase of more FV portions.

Most shoppers lived in close proximity to their market $(66.2 \% \leq 1 \mathrm{~km})$, but a higher share of Cadillac market shoppers lived further away (34 vs. 25\%, cf. Appendix A Table A2) and reported the market to be located on their usual travel route ( $82.1 \mathrm{vs.} 62.5 \%$, data not shown). This underlines the potential for interventions implemented near transportation hubs that ease the combination of activities 
or errands. In fact, it has been reported previously that shoppers preferentially choose farmers' markets that add the least amount of time to their travel rather than the farmers' market that may be closest to their home [101]. Multivariate analyses also reveal a lower number of FV portions and variety of FV purchased when the market was on the travel route $(p=0.03$ and $p<0.01)$. It is possible that shoppers living closer to the markets attended more frequently and, therefore, purchased smaller volumes. Amounts of FV purchased at the markets were also not associated with overall FV consumption, suggesting that FV stands to act as a complementary source of FV, which are otherwise mostly bought in conventional points of sale such as supermarkets. Longitudinal follow-up of shopping patterns could reveal further information with respect to mobility patterns and the importance of secondary food sources for achieving healthier diets. Temporal shopping patterns were not analysed in this study, as we collected information on only one shopping event per participant.

Although physical distance from home to market was controlled for in the present study, a more detailed analysis of daily mobility patterns in light of the environmental circumstances surrounding the market could provide additional insights. Spatial dimensions are rarely reported in existing FM studies, but would be useful for better understanding shopping patterns. Further, understanding such spatial dynamics could be strategic for choosing intervention locations that may be best suited to the needs of the population. Also, much higher traffic was observed for Cadillac market (53 vs. 16 shoppers per day at Guybourg). To ensure economic viability of UPS in poor neighbourhoods while improving access to healthy food, it seems worthwhile to locate these services near transit hubs. Such locations can serve a larger and more diverse clientele, thus reaching the double goal of increasing access to FVs for disadvantaged populations and of optimizing economic survival by also including consumers with higher purchasing power. Those observations concurred with Sadler's findings emphasizing that location of a food market in a prominent and central location is key to increasing access by attracting both residents and broader clientele [35].

Besides accessibility variables, the only other variable that we found to be related to purchase indicators was place of birth, consistent with Canadian data highlighting that immigrants may have healthier eating habits $[102,103]$. Participants born in Canada bought fewer FV portions, less variety and spent less per purchase. Reflecting the composition of the adjacent neighbourhoods, most shoppers were born in Canada (>75\% in our study versus 77\% in 2016 neighbourhood statistics) [104]. The proportion of shoppers living on a low-income was also similar to that of the adjacent neighbourhoods $(23.0 \%$ vs. $16.6 \%$ to $20.3 \%$ ). This suggests that the interventions reached a variety of socioeconomic groups. However, most shoppers were highly educated. This finding is distinct from observations made in low-income communities by Jennings and colleagues in the UK [34], but coincides with those made by Woodruff in the UK, USA and Australia [39].

In our study, the Square application database allowed us to access data for each food item rather than only by food category, unlike existing databases that use barcodes (e.g., Nielsen). Furthermore, we connected purchase data to both point of sale and to the individual shopper. This made it possible to look at three distinct FV purchase indicators: the number of FV portions, the variety of FV purchased per transaction, and the amount spent. The number of FV portions and amount spent are indicators initially developed by the Institut National de Santé Publique du Québec to assess and describe the quality of food consumption in Quebec [57]. These indicators are used in other settings and countries. We encourage future studies to adopt these standards to facilitate comparison between studies, and possibly even compare results to data obtained from existing databases using barcodes such as Nielsen. However, it is still possible to extract raw quantities for broader comparisons. Several countries are implementing laws requiring small companies to adopt electronic billing systems [76], which will facilitate this type of study.

The organization operating the market reported a very positive experience with the Square application as it was an easy-to-use technology. The application also enabled the analysis of traffic and peak hours. Other similar initiatives in Montréal also showed interest in the system for future interventions. However, sellers need to pay user fees, which could be an obstacle for usage in smaller 
settings. For the customer, the application does not add constraints compared to classical retailers. Furthermore, shoppers could pay either cash or by credit card, which is not always the case in that type of venue, thus increasing economic accessibility.

The use of an electronic payment application also enables standardization in purchase data entry. In addition, manual recording is not only time-consuming and resource-intensive but also presents the risk of missed transactions, especially during busy hours [43,56,59,71,72,75,105]. Alia et al. highlighted the potential for electronic application to collect purchase data in UPS [56].

Like every new method, the use of Square also presented a few challenges. We found that data accuracy depends largely on the research assistants, who need to be properly trained to avoid mistakes when documenting details of the transaction (date, time, and list of some items). In our case, the FV stands studied did not have very high traffic, facilitating documentation and the subsequent retrieval of the right transaction. However, in venues with higher traffic, we recommend the procedure to be adapted to ensure survey data can accurately be linked to transaction data. Another possible source of error might be linked to the accuracy and precision of the vendor who registers the purchases into the application. However, as the application also helps to identify the right amount to be paid, there is no reason the vendor would purposefully generate errors.

We would like to highlight several strengths of this study. This is one of the first studies that attempts to automatically quantify purchasing data on a local and provisional food source, on two separate sites, taking into account several spatial variables. The few studies that examined sales data from farmers' market interventions mainly focused on the impact of financial incentives for purchasing FV [43,59,61-66]. These reported the amount spent by shoppers and/or type of purchase, but did not assess other factors associated with FV purchase. One limitation is that it is difficult to make comparisons between studies since prices and types of FV can vary widely between countries and regions. The proposed purchase analysis allows a gap in the literature to be filled as it enables the analysis of quantities of FV purchased, which helps understanding dietary health practices and enables comparison across contexts. Furthermore, the available information makes the calculation of the average price per portion of FV possible. Another strength of the method is the consideration of the edible portion of FV rather than the total weight purchased, which is more relevant in terms of consumption.

Several limitations need to be underlined. The sample size was relatively small and models may have lacked statistical power. Even though similar studies use the same type of cross-sectional design, results need to be interpreted with caution as we cannot establish any causal relationships. As this study occurred in a natural setting, several parameters could not be controlled by the researchers, thus limiting deeper analyses. While Guybourg shoppers reported a higher visit frequency to the market (one-time-only visits were reported as $62.7 \%$ in Cadillac vs. $42.9 \%$ in Guybourg), interpretation is limited as implementation duration was different during the 2016 season (14 days at Cadillac vs. 45 days at Guybourg). Awareness of the market and adoption among the local population also differed (data not shown). Although Cadillac opened later in the season (Sept-Oct), data at both markets were collected during the same period. An overview of the data confirmed that available species of FV were globally the same for both markets during the study period. Furthermore, the use of the Square application could present acceptability issues for some merchants accustomed to accepting only cash because recording every transaction may have repercussions for tax returns. This could be a factor limiting its use and expansion in intervention studies or public health interventions.

\section{Conclusions}

This study presents an innovative method for measuring FV practices using purchase data from a mobile application that allowed us to analyse the links between socioeconomic factors, subjective and objective variables of food environments, spatial- and mobility-related factors, and purchase of $\mathrm{FV}$ among participants in disadvantaged neighbourhoods. Because it does not require an optical scan system, this purchase analysis method could be easy to apply in both unconventional points of 
sales research and in public health interventions. In order to evaluate more accurately the impact on diet of food environment interventions, we need to deepen our understanding of the complexity of food shopping practices. With many quasi-natural experimental opportunities arising from local food environment interventions and increasing adoption of UPS, the use of objective indicators of food shopping practices as proposed here offers new ways to explore food-related health and inequities. The tools and indicators used in this study could be easily applied to other countries and other settings.

Author Contributions: Conceptualization, Y.K., S.C., L.D. and G.M.; Formal analysis, P.R.; Funding acquisition, Y.K. and G.M.; Investigation, S.C.; Methodology, P.R., Y.K., S.C., L.D. and G.M.; Project administration, Y.K. and G.M.; Supervision, G.M.; Writing-original draft, P.R. and S.B.; Writing—review \& editing, Y.K., G.M. and S.C. All authors have read and agreed to the published version of the manuscript.

Funding: This study was supported by a grant from Québec en forme and financed by the CIHR Chair in Applied Public Health on Urban Interventions and Population Health. Pauline Rebouillat was financially supported by the CIHR Chair in Applied Public Health on Urban Interventions and Population Health. Sarah Chaput was financially supported by the CIHR Chair in Applied Public Health on Urban Interventions and Population Health, the Département de médecine sociale et préventive, the Observatoire québécois sur la qualité de l'offre alimentaire and the Faculté des études supérieures et postdoctorales. Yan Kestens holds a CIHR Chair in Applied Public Health on Urban Interventions and Population Health. Geneviève Mercille was financially supported by a grant from the Population Health Intervention Research Network (PHIRNET) during the conceptualization of this study.

Acknowledgments: The authors would like to thank Athanasios Tommy Mihou from Y'a QuelQu'un l'aut'bord du mur, the Montreal Public Health Department and Jean-Philippe Vermette from the Montréal Public Market Management Corporation for their collaboration with this study. The authors also thank Ruben Brondeel for his help with the Square database data management, Benoit Thierry for spatial parameters computation and Ana Deaconu for her help with the revision of the manuscript.

Conflicts of Interest: The authors declare no conflict of interest. The funders had no role in the design of the study, in the collection, analyses, or interpretation of data, in the writing of the manuscript, or in the decision to publish the results.

\section{Appendix A}

Table A1. Characteristics of market food shoppers by market location $(n=257)$.

\begin{tabular}{|c|c|c|c|c|c|}
\hline Variables & $\begin{array}{l}\text { Cadillac Shoppers } \\
\qquad(n=201)\end{array}$ & SD & $\begin{array}{c}\text { Guybourg } \\
\text { Shoppers }(n=56)\end{array}$ & SD & $p$-Value \\
\hline \multicolumn{6}{|l|}{ Sociodemographic characteristics } \\
\hline \multicolumn{6}{|l|}{ Age, years $(\%)$} \\
\hline $18-44$ & 46.8 & - & 51.8 & - & \multirow[t]{3}{*}{$0.017^{\mathrm{a}}$} \\
\hline $45-64$ & 34.3 & - & 44.6 & - & \\
\hline 65 and over & 18.9 & - & 3.6 & - & \\
\hline \multicolumn{6}{|l|}{$\operatorname{Sex}(\%)$} \\
\hline Male & 18.5 & - & 33.9 & - & \multirow{3}{*}{$0.014^{\mathrm{a}}$} \\
\hline Female & 81.5 & - & 66.1 & - & \\
\hline Missing & 0.0 & - & 0.5 & - & \\
\hline Household size & 2.1 & 1.1 & 2.6 & 1.3 & $0.02^{b}$ \\
\hline \multicolumn{6}{|l|}{ Education (\%) } \\
\hline High school or less & 24.9 & - & 21.4 & - & \multirow{3}{*}{$0.78^{\mathrm{a}}$} \\
\hline Trade school or pre-university & 36.3 & _- & 41.1 & _- & \\
\hline $\begin{array}{l}\text { college } \\
\text { University }\end{array}$ & 38.8 & - & 37.5 & - & \\
\hline \multicolumn{6}{|l|}{ Household under the LIM (\%) } \\
\hline Yes & 24.4 & - & 17.9 & - & \multirow{3}{*}{$0.31^{\mathrm{a}}$} \\
\hline No & 60.7 & - & 66.1 & - & \\
\hline Missing & 14.9 & - & 16.1 & - & \\
\hline \multicolumn{6}{|l|}{ Born in Canada (\%) } \\
\hline Yes & 77.6 & - & 80.4 & - & \multirow[t]{2}{*}{$0.66^{\mathrm{a}}$} \\
\hline No & 22.4 & - & 19.6 & - & \\
\hline \multicolumn{6}{|l|}{ Geographic and mobility variables } \\
\hline Car access $(\%)$ & & & & & \multirow{3}{*}{$<0.0001^{a}$} \\
\hline Yes & 46.8 & - & 87.5 & - & \\
\hline No & 53.2 & - & 12.5 & - & \\
\hline
\end{tabular}


Table A1. Cont.

\begin{tabular}{|c|c|c|c|c|c|}
\hline Variables & $\begin{array}{l}\text { Cadillac Shoppers } \\
\quad(n=201)\end{array}$ & SD & $\begin{array}{c}\text { Guybourg } \\
\text { Shoppers }(n=56)\end{array}$ & SD & $p$-Value \\
\hline Home-to-market distance, meters & 2085.7 & 3635.4 & 1659.5 & 3430.4 & $<0.0001^{b}$ \\
\hline $\begin{array}{l}\text { Residing } \leq 1 \mathrm{~km} \text { from the market } \\
(\%) \\
\text { Yes }\end{array}$ & 63.7 & & 75.0 & & 0.11 \\
\hline Unhealthy/healthy densities ratio & 2.8 & 0.6 & 3.1 & 0.5 & $0.0003^{c}$ \\
\hline $\begin{array}{l}\text { Market on usual travel route }(\%) \\
\text { Yes } \\
\text { No } \\
\text { Missing }\end{array}$ & $\begin{array}{c}82.1 \\
17.9 \\
0.0\end{array}$ & $\begin{array}{l}- \\
- \\
-\end{array}$ & $\begin{array}{c}62.5 \\
33.9 \\
3.6\end{array}$ & $\begin{array}{l}- \\
- \\
-\end{array}$ & $0.01^{\mathrm{a}}$ \\
\hline $\begin{array}{l}\text { FV consumption, perceived access } \\
\text { and shopping habits }\end{array}$ & & & & & $0.94^{\mathrm{c}}$ \\
\hline $\begin{array}{l}\text { Fruit and vegetable consumption } \\
\text { per day }\end{array}$ & 4.6 & 2.0 & 4.6 & 2.1 & \\
\hline $\begin{array}{l}\text { Easy to find fresh FV of good } \\
\text { quality in own neighbourhood (\%) } \\
\text { Agree } \\
\text { More or less agree } \\
\text { Disagree } \\
\text { Missing }\end{array}$ & $\begin{array}{c}46.8 \\
17.9 \\
34.3 \\
1.0\end{array}$ & $\begin{array}{l}- \\
- \\
- \\
-\end{array}$ & $\begin{array}{c}48.2 \\
5.4 \\
46.4 \\
0.0\end{array}$ & $\begin{array}{l}- \\
- \\
- \\
-\end{array}$ & $0.04^{\mathrm{a}}$ \\
\hline $\begin{array}{l}\text { Fresh FV are not affordable in own } \\
\text { neighbourhood (\%) } \\
\text { Agree } \\
\text { More or less agree } \\
\text { Disagree } \\
\text { Missing } \\
\end{array}$ & $\begin{array}{l}31.8 \\
16.4 \\
48.3 \\
3.5\end{array}$ & $\begin{array}{l}- \\
- \\
-\end{array}$ & $\begin{array}{c}16.1 \\
8.9 \\
69.6 \\
5.4 \\
\end{array}$ & $\begin{array}{l}- \\
- \\
-\end{array}$ & $0.01^{\mathrm{a}}$ \\
\hline $\begin{array}{l}\text { Easy to purchase fresh FV within } \\
\text { walking distance from home (\%) } \\
\text { Agree } \\
\text { More or less agree } \\
\text { Disagree } \\
\text { Missing } \\
\end{array}$ & $\begin{array}{c}63.7 \\
5.5 \\
30.4 \\
0.5\end{array}$ & $\begin{array}{l}- \\
- \\
- \\
-\end{array}$ & $\begin{array}{c}44.6 \\
7.1 \\
48.2 \\
0.0\end{array}$ & $\begin{array}{l}- \\
- \\
- \\
-\end{array}$ & $0.03^{\mathrm{d}}$ \\
\hline $\begin{array}{l}\text { Easy to purchase fresh FV on usual } \\
\text { travel route }(\%) \\
\text { Agree } \\
\text { More or less agree } \\
\text { Disagree } \\
\text { Missing }\end{array}$ & $\begin{array}{c}63.7 \\
4.0 \\
31.3 \\
1.0\end{array}$ & $\begin{array}{l}- \\
- \\
-\end{array}$ & $\begin{array}{c}67.9 \\
1.8 \\
28.6 \\
1.8\end{array}$ & $\begin{array}{l}- \\
- \\
- \\
-\end{array}$ & $0.03^{\mathrm{d}}$ \\
\hline $\begin{array}{l}\text { Market shopping habits (\%) } \\
\text { Less than once a month } \\
1 \text { to } 3 \text { times/month } \\
\text { Once a week or more } \\
\text { Missing }\end{array}$ & $\begin{array}{c}26.4 \\
26.9 \\
45.3 \\
1.5 \\
\end{array}$ & $\begin{array}{l}- \\
- \\
- \\
-\end{array}$ & $\begin{array}{c}8.9 \\
21.4 \\
66.1 \\
3.6 \\
\end{array}$ & $\begin{array}{l}- \\
- \\
- \\
-\end{array}$ & $0.01^{\mathrm{a}}$ \\
\hline $\begin{array}{l}\text { Number of visits at the } \\
\text { intervention market (\%) } \\
\text { One visit } \\
\text { Between one visit total and one } \\
\text { visit } \\
\text { per month } \\
\text { More than one visit per month }\end{array}$ & $\begin{array}{l}62.7 \\
28.9\end{array}$ & $\begin{array}{l}- \\
- \\
-\end{array}$ & $\begin{array}{l}42.9 \\
32.1 \\
25.0\end{array}$ & $\begin{array}{l}- \\
- \\
-\end{array}$ & $0.002^{\mathrm{a}}$ \\
\hline Purchasing practice analysis & & & & & \\
\hline Number of FV portions & 12.6 & 11.5 & 21.1 & 20.1 & $0.002^{b}$ \\
\hline Variety of FV purchased & 2.7 & 1.9 & 3.3 & 2.5 & $0.12^{b}$ \\
\hline Amount spent (CAD) & 4.8 & 3.8 & 5.7 & 4.2 & $0.09^{\mathrm{b}}$ \\
\hline
\end{tabular}


Table A2. Supplemental characteristics of market food shoppers $(n=257)$.

\begin{tabular}{|c|c|c|}
\hline Variables & Cadillac Shoppers $(n=201)$ & Guybourg Shoppers $(n=56)$ \\
\hline \multicolumn{3}{|l|}{ Households with children (\%) } \\
\hline Yes & 24.4 & 35.7 \\
\hline \multicolumn{3}{|l|}{ Single-individual home (\%) } \\
\hline Yes & 37.3 & 25.0 \\
\hline \multicolumn{3}{|l|}{ Household income (\%) } \\
\hline$<20.000$ & 14.4 & 7.1 \\
\hline $20-29.999$ & 17.9 & 8.9 \\
\hline 30-39.999 & 10.0 & 10.7 \\
\hline $40-49.999$ & 11.4 & 8.9 \\
\hline $50-59.999$ & 9.5 & 8.9 \\
\hline $60-79.999$ & 7.5 & 12.5 \\
\hline 80-99.999 & 5.5 & 8.9 \\
\hline$\geq 100.000$ & 9.0 & 17.9 \\
\hline Missing & 14.9 & 16.1 \\
\hline \multicolumn{3}{|l|}{$\begin{array}{l}\text { Household main source of } \\
\text { income }(\%)\end{array}$} \\
\hline Salary or self-employment & 62.7 & 75.0 \\
\hline Retirement income & 20.4 & 10.7 \\
\hline Social Welfare & 11.9 & 8.9 \\
\hline Other & 2.5 & 3.6 \\
\hline Missing & 2.5 & 1.8 \\
\hline \multicolumn{3}{|l|}{ Transport to the market (\%) } \\
\hline Subway & 49.3 & 0 \\
\hline Bus & 5.5 & 3.6 \\
\hline Car & 2.5 & 33.9 \\
\hline Bike & 1.0 & 7.1 \\
\hline Walk & 41.8 & 55.4 \\
\hline \multicolumn{3}{|l|}{ Transport from the market (\%) } \\
\hline Subway & 14.4 & 0 \\
\hline Bus & 10.5 & 3.6 \\
\hline Car & 6.5 & 33.9 \\
\hline Bike & 0.5 & 7.1 \\
\hline Walk & 68.2 & 55.4 \\
\hline \multicolumn{3}{|l|}{ Eats $5 F V$ a day $(\%)$} \\
\hline Yes & 42.8 & 37.5 \\
\hline No & 56.2 & 62.5 \\
\hline Missing & 1.0 & 0.0 \\
\hline \multicolumn{3}{|l|}{$\begin{array}{l}\text { Responsibility level for } \\
\text { household } \\
\text { food shopping (\%) }\end{array}$} \\
\hline Mainly responsible & 69.2 & 75.0 \\
\hline Shared responsibility (50-50) & 24.4 & 17.9 \\
\hline Occasionally responsible & 5.5 & 5.4 \\
\hline Not responsible & 0.5 & 0.0 \\
\hline Missing & 0.5 & 1.8 \\
\hline
\end{tabular}

\section{References}

1. McGrail, K.M.; Van Doorslaer, E.; Ross, N.A.; Sanmartin, C. Income-related health inequalities in Canada and the United States: A decomposition analysis. Am. J. Public Health 2009, 99, 1856-1863. [CrossRef]

2. Ezzati, M.; Friedman, A.B.; Kulkarni, S.C.; Murray, C.J. The reversal of fortunes: Trends in county mortality and cross-county mortality disparities in the United States. PLoS Med. 2008, 5, e66. 
3. Mackenbach, J.P.; Stirbu, I.; Roskam, A.-J.R.; Schaap, M.M.; Menvielle, G.; Leinsalu, M.; Kunst, A.E. Socioeconomic inequalities in health in 22 European countries. N. Engl. J. Med. 2008, 358, 2468-2481. [CrossRef] [PubMed]

4. Darmon, N.; Drewnowski, A. Does social class predict diet quality? Am. J. Clin. Nutr. 2008, 87, 1107-1117. [CrossRef] [PubMed]

5. Kamphuis, C.B.; Giskes, K.; de Bruijn, G.-J.; Wendel-Vos, W.; Brug, J.; Van Lenthe, F.J. Environmental determinants of fruit and vegetable consumption among adults: A systematic review. Br. J. Nutr. 2006, 96, 620-635.

6. Boeing, H.; Bechthold, A.; Bub, A.; Ellinger, S.; Haller, D.; Kroke, A.; Leschik-Bonnet, E.; Müller, M.J.; Oberritter, H.; Schulze, M. Critical review: Vegetables and fruit in the prevention of chronic diseases. Eur. J. Nutr. 2012, 51, 637-663. [CrossRef]

7. Cannuscio, C.C.; Tappe, K.; Hillier, A.; Buttenheim, A.; Karpyn, A.; Glanz, K. Urban food environments and residents' shopping behaviors. Am. J. Prev. Med. 2013, 45, 606-614. [CrossRef]

8. Zachary, D.A.; Palmer, A.M.; Beckham, S.W.; Surkan, P.J. A framework for understanding grocery purchasing in a low-income urban environment. Qual. Health Res. 2013, 23, 665-678. [CrossRef]

9. Beagan, B.L.; Power, E.M.; Chapman, G.E. "Eating isn't just swallowing food": Food practices in the context of social class trajectory. Can. Food Stud. Rev. Can. Etudes L'alimentation 2015, 2, 75-98. [CrossRef]

10. Clifton, K.J. Mobility strategies and food shopping for low-income families: A case study. J. Plan. Educ. Res. 2004, 23, 402-413. [CrossRef]

11. Fish, C.A.; Brown, J.R.; Quandt, S.A. African American and Latino low income families' food shopping behaviors: Promoting fruit and vegetable consumption and use of alternative healthy food options. J. Immigr. Minority Health 2015, 17, 498-505. [CrossRef]

12. Tach, L.; Amorim, M. Constrained, convenient, and symbolic consumption: Neighborhood food environments and economic coping strategies among the urban poor. J. Urban Health 2015, 92, 815-834. [CrossRef] [PubMed]

13. Zenk, S.N.; Odoms-Young, A.M.; Dallas, C.; Hardy, E.; Watkins, A.; Hoskins-Wroten, J.; Holland, L. “You Have to Hunt for the Fruits, the Vegetables": Environmental Barriers and Adaptive Strategies to Acquire Food in a Low-Income African American Neighborhood. Health Educ. Behav. 2011, 38, 282-292. [CrossRef] [PubMed]

14. Centers for Disease Control Prevention. Strategies to Prevent Obesity and Other Chronic Diseases: The CDC Guide to Strategies to Increase the Consumption of Fruits and Vegetables; US Department of Health and Human Services: Atlanta, GA, USA, 2011.

15. SAM; CRÉ. Plan de Développement d'un Système Alimentaire Equitable et Durable de la Collectivité Montréalaise (SAM 2025): Innover Pour Mieux se Nourrir et se Développer In Canada. 2014, p. 28. Available online: https://sam.montrealmetropoleensante.ca/uploads/resources/files/document\%20complet\%20SAM\% 202025.pdf (accessed on 21 December 2019).

16. Food and Urban Agriculture Advisory Committee. FRESH: Edmonton's Food and Urban Agriculture Strategy; Food and Urban Agriculture Advisory Committee: New York, NY, USA, 2012.

17. Toronto Public Health. Toronto Food Strategy 2018 Report: HL28.04 Attachment 1; Toronto Public Health: Toronto, ON, Canada, 2018; p. 33.

18. Aubé, J.; Marquis, M. Circuits courts de distribution de legumes: Impacts potentiels sur les saines habitudes alimentaires. In Agriculture Urbaine: Aménager et Nourrir la Ville; Les Editions en Environnement VertigO, Ed.; Éric Duchemin (dir.): Montréal, QC, Canada, 2013; p. 353.

19. Mundler, P.; Laughrea, S. Quels Bénéfices Pour le Développement des Territoires? Étude de Cas Dans Trois Territoires Québécois; Rapport final de recherche remis au CIRANO; Université Laval: Québec, QC, Canada, 2015; p. 124.

20. Dodds, R.; Holmes, M.; Arunsopha, V.; Chin, N.; Le, T.; Maung, S.; Shum, M. Consumer choice and farmers' markets. J. Agric. Environ. Ethics 2014, 27, 397-416. [CrossRef]

21. Feagan, R.; Morris, D.; Krug, K. Niagara region farmers' markets: Local food systems and sustainability considerations. Local Environ. 2004, 9, 235-254. [CrossRef]

22. Freedman, D.A.; Vaudrin, N.; Schneider, C.; Trapl, E.; Ohri-Vachaspati, P.; Taggart, M.; Ariel Cascio, M.; Walsh, C.; Flocke, S. Systematic Review of Factors Influencing Farmers' Market Use Overall and among Low-Income Populations. J. Acad Nutr. Diet. 2016, 116, 1136-1155. [CrossRef] [PubMed] 
23. Jilcott Pitts, S.B.; Wu, Q.; Demarest, C.L.; Dixon, C.E.; Dortche, C.J.; Bullock, S.L.; McGuirt, J.; Ward, R.; Ammerman, A.S. Farmers' market shopping and dietary behaviours among Supplemental Nutrition Assistance Program participants. Public Health Nutr. 2015, 18, 2407-2414. [CrossRef] [PubMed]

24. McCormack, L.A.; Laska, M.N.; Larson, N.I.; Story, M. Review of the nutritional implications of farmers' markets and community gardens: A call for evaluation and research efforts. J. Am. Diet. Assoc. 2010, 110, 399-408. [CrossRef] [PubMed]

25. Woodruff, R.C.; Raskind, I.G.; Harris, D.M.; Gazmararian, J.A.; Kramer, M.; Haardörfer, R.; Kegler, M.C. The dietary impact of introducing new retailers of fruits and vegetables into a community: Results from a systematic review. Public Health Nutr. 2018, 21, 981-991. [CrossRef]

26. Zepeda, L.; Reznickova, A.; Lohr, L. Overcoming challenges to effectiveness of mobile markets in US food deserts. Appetite 2014, 79, 58-67. [CrossRef]

27. Wetherill, M.S.; Gray, K.A. Farmers' markets and the local food environment: Identifying perceived accessibility barriers for SNAP consumers receiving temporary assistance for needy families (TANF) in an urban Oklahoma community. J. Nutr. Educ. Behav. 2015, 47, 127-133. [CrossRef] [PubMed]

28. Colasanti, K.J.; Conner, D.S.; Smalley, S.B. Understanding barriers to farmers' market patronage in Michigan: Perspectives from marginalized populations. J. Hunger Environ. Nutr. 2010, 5, 316-338. [CrossRef]

29. McGuirt, J.T.; Jilcott Pitts, S.B.; Ward, R.; Crawford, T.W.; Keyserling, T.C.; Ammerman, A.S. Examining the Influence of price and accessibility on willingness to shop at farmers' markets among low-income eastern North Carolina women. J. Nutr. Educ. Behav. 2014, 46, 26-33. [CrossRef] [PubMed]

30. Farmer, J.; Minard, S.; Edens, C. Local foods and low-income communities: Location, transportation, and values. J. Agric. Food Syst. Community Dev. 2016, 6, 41-53. [CrossRef]

31. Freedman, D.A.; Blake, C.E.; Liese, A.D. Developing a Multicomponent Model of Nutritious Food Access and Related Implications for Community and Policy Practice. J. Community Pract. 2013, 21, 379-409. [CrossRef]

32. Valchuis, L.; Conner, D.S.; Berlin, L.; Wang, Q. Stacking Beliefs and Participation in Alternative Food Systems. J. Hunger Environ. Nutr. 2015, 10, 214-229. [CrossRef]

33. Freedman, D.A. A community health case study: Creating a food oasis in a food desert. Community Psychol. 2007, 40, 67-70.

34. Jennings, A.; Cassidy, A.; Winters, T.; Barnes, S.; Lipp, A.; Holland, R.; Welch, A. Positive effect of a targeted intervention to improve access and availability of fruit and vegetables in an area of deprivation. Health Place 2012, 18, 1074-1078. [CrossRef]

35. Sadler, R.C. Strengthening the core, improving access: Bringing healthy food downtown via a farmers' market move. Appl. Geogr. 2016, 67, 119-128. [CrossRef]

36. Feagan, R.B.; Morris, D. Consumer quest for embeddedness: A case study of the Brantford Farmers' Market. Int. J. Consum. Stud. 2009, 33, 235-243. [CrossRef]

37. Smithers, J.; Lamarche, J.; Joseph, A.E. Unpacking the terms of engagement with local food at the farmers' market: Insights from Ontario. J. Rural Stud. 2008, 24, 337-350. [CrossRef]

38. Byker, C.; Shanks, J.; Misyak, S.; Serrano, E. Characterizing farmers' market shoppers: A literature review. J. Hunger Environ. Nutr. 2012, 7, 38-52. [CrossRef]

39. Woodruff, R.C.; Coleman, A.-M.; Hermstad, A.K.; Honeycutt, S.; Munoz, J.; Loh, L. Increasing Community Access to Fresh Fruits and Vegetables: A Case Study of the Farm Fresh Market Pilot Program in Cobb County, Georgia, 2014. Prev. Chronic Dis. 2016, 13, E36. [CrossRef] [PubMed]

40. Jilcott Pitts, S.B.; Wu, Q.; McGuirt, J.T.; Crawford, T.W.; Keyserling, T.C.; Ammerman, A.S. Associations between access to farmers' markets and supermarkets, shopping patterns, fruit and vegetable consumption and health indicators among women of reproductive age in eastern North Carolina, U.S.A. Public Health Nutr. 2013, 16, 1944-1952. [CrossRef]

41. Jilcott Pitts, S.B.; Gustafson, A.; Wu, Q.; Leah Mayo, M.; Ward, R.K.; McGuirt, J.T.; Rafferty, A.P.; Lancaster, M.F.; Evenson, K.R.; Keyserling, T.C.; et al. Farmers' market use is associated with fruit and vegetable consumption in diverse southern rural communities. Nutr. J. 2014, 13, 1. [CrossRef]

42. Evans, A.E.; Jennings, R.; Smiley, A.W.; Medina, J.L.; Sharma, S.V.; Rutledge, R.; Stigler, M.H.; Hoelscher, D.M. Introduction of farm stands in low-income communities increases fruit and vegetable among community residents. Health Place 2012, 18, 1137-1143. [CrossRef] 
43. Freedman, D.A.; Choi, S.K.; Hurley, T.; Anadu, E.; Hebert, J.R. A Farmers' Market at a Federally Qualified Health Center Improves Fruit and Vegetable Intake among Low-income Diabetics. Prev. Med. 2013, 56, 288-292. [CrossRef]

44. Jilcott Pitts, S.B.; McGuirt, J.T.; Wu, Q.; Rushing, J.; Uslan, D.; Stanley, K.K.; Bullock, S.L.; Ward, R.K.; Rafferty, A.P.; Ammerman, A.S. Assessing Preliminary Impact of the North Carolina Community Transformation Grant Project Farmers' Market Initiatives Among Rural Residents. J. Nutr. Educ. Behav. 2016, 48, 343-349. [CrossRef]

45. Dimitri, C.; Oberholtzer, L.; Nischan, M. Reducing the Geographic and Financial Barriers to Food Access: Perceived Benefits of Farmers' Markets and Monetary Incentives. J. Hunger Environ. Nutr. 2013, 8, 429-444. [CrossRef]

46. Olsho, L.E.; Payne, G.H.; Walker, D.K.; Baronberg, S.; Jernigan, J.; Abrami, A. Impacts of a farmers' market incentive programme on fruit and vegetable access, purchase and consumption. Public Health Nutr. 2015, 18, 2712-2721. [CrossRef]

47. Savoie-Roskos, M.; Durward, C.; Jeweks, M.; LeBlanc, H. Reducing Food Insecurity and Improving Fruit and Vegetable Intake Among Farmers' Market Incentive Program Participants. J. Nutr. Educ. Behav. 2016, 48, 70-76. [CrossRef] [PubMed]

48. Wheeler, A.L.; Chapman-Novakofski, K. Farmers' markets: Costs compared with supermarkets, use among WIC clients, and relationship to fruit and vegetable intake and related psychosocial variables. J. Nutr. Educ. Behav. 2014, 46 (Suppl. S3), S65-S70. [CrossRef]

49. Young, C.R.; Aquilante, J.L.; Solomon, S.; Colby, L.; Kawinzi, M.A.; Uy, N.; Mallya, G. Improving fruit and vegetable consumption among low-income customers at farmers markets: Philly Food Bucks, Philadelphia, Pennsylvania, 2011. Prev. Chronic Dis. 2013, 10, E166. [CrossRef] [PubMed]

50. Halimatou, A.; Navaugh, F.; Kara, J.; Abigail, P. Farmers' market use is associated with fruit and vegetable consumption among low-income populations: A cross-sectional study from Southern Arizona. J. Nutr. Health Sci. 2017, 4, 201.

51. Payet, J.; Gilles, M.; Howat, P. Gascoyne Growers Market: A sustainable health promotion activity developed in partnership with the community. Aust. J. Rural Health 2005, 13, 309-314. [CrossRef] [PubMed]

52. Ruelas, V.; Iverson, E.; Kiekel, P.; Peters, A. The role of farmers' markets in two low income, urban communities. J. Community Health 2012, 37, 554-562. [CrossRef] [PubMed]

53. Abusabha, R.; Namjoshi, D.; Klein, A. Increasing access and affordability of produce improves perceived consumption of vegetables in low-income seniors. J. Am. Diet. Assoc. 2011, 111, 1549-1555. [CrossRef]

54. Woodruff, R.C.; Arriola, K.J.; Powell-Threets, K.; Nuri, K.R.; Hunter, C.; Kegler, M.C. Urban Farmers Markets as a Strategy to Increase Access to and Consumption of Fresh Vegetables among SNAP and Non-SNAP Participants. J. Agric. Food Syst. Community Dev. 2018, 8, 1-13. [CrossRef]

55. Gorham, G.; Dulin-Keita, A.; Risica, P.M.; Mello, J.; Papandonatos, G.; Nunn, A.; Gorham, S.; Roberson, M.; Gans, K.M. Effectiveness of Fresh to You, a Discount Fresh Fruit and Vegetable Market in Low-Income Neighborhoods, on Children's Fruit and Vegetable Consumption, Rhode Island, 2010-2011. Prev. Chronic Dis. 2015, 12, E176. [CrossRef]

56. Alia, K.A.; Freedman, D.A.; Brandt, H.M.; Gibson-Haigler, P.; Friedman, D.B. A Participatory Model for Evaluating a Multilevel Farmers' Market Intervention. In Progress in Community Health Partnerships: Research, Education, and Action; Johns Hopkins University Press: Baltimore, MD, USA, 2015; Volume 9, pp. 537-548.

57. Paquette, M.-C.; Bergeron, P. Cadre de Référence des Indicateurs D'achats Pour Caractériser L'alimentation et L'environnement Alimentaire au Quebec; Institut national de santé publique du Québec: Québec, QC, Canada, 2016.

58. Mamiya, H.; Moodie, E.E.M.; Buckeridge, D.L. A novel application of point-of-sales grocery transaction data to enhance community nutrition monitoring. AMIA Annu. Symp. Proc. AMIA Symp. 2018, 2017, 1253-1261.

59. Freedman, D.A.; Bell, B.A.; Collins, L.V. The Veggie Project: A case study of a multi-component farmers' market intervention. J. Prim. Prev. 2011, 32, 213-224. [CrossRef] [PubMed]

60. Varner, T.; Otto, D. Factors affecting sales at farmers' markets: An Iowa study. Rev. Agric. Econ. 2008, 30, 176-189. [CrossRef]

61. Baronberg, S.; Dunn, L.; Nonas, C.; Dannefer, R.; Sacks, R. The impact of New York City's Health Bucks Program on electronic benefit transfer spending at farmers markets, 2006-2009. Prev. Chronic Dis. 2013, 10, E163. [CrossRef] [PubMed] 
62. Robles, B.; Montes, C.E.; Nobari, T.Z.; Wang, M.C.; Kuo, T. Dietary Behaviors among Public Health Center Clients with Electronic Benefit Transfer Access at Farmers' Markets. J. Acad. Nutr. Diet. 2017, 117, $58-68$. [CrossRef]

63. Buttenheim, A.M.; Havassy, J.; Fang, M.; Glyn, J.; Karpyn, A.E. Increasing Supplemental Nutrition Assistance Program/Electronic Benefits Transfer Sales at Farmers' Markets with Vendor-Operated Wireless Point-of-Sale Terminals. J. Acad. Nutr. Diet. 2012, 112, 636-641. [CrossRef]

64. Anderson, J.V.; Bybee, D.I.; Brown, R.M.; McLean, D.F.; Garcia, E.M.; Breer, M.L.; Schillo, B.A. 5 A Day Fruit and Vegetable Intervention Improves Consumption in a Low Income Population. J. Am. Diet. Assoc. 2001, 101, 195-202. [CrossRef]

65. Herman, D.R.; Harrison, G.G.; Jenks, E. Choices made by low-income women provided with an economic supplement for fresh fruit and vegetable purchase. J. Am. Diet. Assoc. 2006, 106, 740-744. [CrossRef]

66. Lindsay, S.; Lambert, J.; Penn, T.; Hedges, S.; Ortwine, K.; Mei, A.; Delaney, T.; Wooten, W.J. Monetary matched incentives to encourage the purchase of fresh fruits and vegetables at farmers markets in underserved communities. Prev. Chronic Dis. 2013, 10, E188. [CrossRef]

67. Malagon-Zaldua, E.; Begiristain-Zubillaga, M.; Onederra-Aramendi, A. Measuring the economic impact of farmers' markets on local economies in the basque country. Agriculture 2018, 8, 10. [CrossRef]

68. Lent, M.R.; Vander Veur, S.; Mallya, G.; McCoy, T.A.; Sanders, T.A.; Colby, L.; Rauchut Tewksbury, C.; Lawman, H.G.; Sandoval, B.; Sherman, S.; et al. Corner store purchases made by adults, adolescents and children: Items, nutritional characteristics and amount spent. Public Health Nutr. 2015, 18, 1706-1712. [CrossRef]

69. Lent, M.R.; Vander Veur, S.S.; McCoy, T.A.; Wojtanowski, A.C.; Sandoval, B.; Sherman, S.; Komaroff, E.; Foster, G.D. A randomized controlled study of a healthy corner store initiative on the purchases of urban, low-income youth. Obesity (Silver Spring Md.) 2014, 22, 2494-2500. [CrossRef] [PubMed]

70. Budd, N.; Jeffries, J.K.; Jones-Smith, J.; Kharmats, A.; McDermott, A.Y.; Gittelsohn, J. Store-directed price promotions and communications strategies improve healthier food supply and demand: Impact results from a randomized controlled, Baltimore City store-intervention trial. Public Health Nutr. 2017, 20, 3349-3359. [CrossRef] [PubMed]

71. Caspi, C.E.; Lenk, K.; Pelletier, J.E.; Barnes, T.L.; Harnack, L.; Erickson, D.J.; Laska, M.N. Food and beverage purchases in corner stores, gas-marts, pharmacies and dollar stores. Public Health Nutr. 2017, 20, 2587-2597. [CrossRef] [PubMed]

72. Caspi, C.E.; Lenk, K.; Pelletier, J.E.; Barnes, T.L.; Harnack, L.; Erickson, D.J.; Laska, M.N. Association between store food environment and customer purchases in small grocery stores, gas-marts, pharmacies and dollar stores. Int. J. Behav. Nutr. Phys. Act. 2017, 14, 76. [CrossRef] [PubMed]

73. Ortega, A.N.; Albert, S.L.; Chan-Golston, A.M.; Langellier, B.A.; Glik, D.C.; Belin, T.R.; Garcia, R.E.; Brookmeyer, R.; Sharif, M.Z.; Prelip, M.L. Substantial improvements not seen in health behaviors following corner store conversions in two Latino food swamps. BMC Public Health 2016, 16, 389. [CrossRef] [PubMed]

74. Thorndike, A.N.; Bright, O.M.; Dimond, M.A.; Fishman, R.; Levy, D.E. Choice architecture to promote fruit and vegetable purchases by families participating in the Special Supplemental Program for Women, Infants, and Children (WIC): Randomized corner store pilot study. Public Health Nutr. 2017, 20, 1297-1305. [CrossRef]

75. Ruff, R.R.; Akhund, A.; Adjoian, T. Small Convenience Stores and the Local Food Environment: An Analysis of Resident Shopping Behavior Using Multilevel Modeling. Am. J. Health Promot. AJHP 2016, 30, 172-180. [CrossRef]

76. Ministère de l'Économie et des Finances Marchés Publics. La Facturation Par Voie Electronique Obligatoire dès 2017. Available online: https://www.economie.gouv.fr/entreprises/marches-publics-facture-electronique (accessed on 21 December 2019).

77. Minaker, L.M.; Lynch, M.; Cook, B.E.; Mah, C.L. Exploring sales data during a healthy corner store intervention in Toronto: The Food Retail Environments Shaping Health (FRESH) project. Health Promot. Chronic Dis. Prev. Can. Res. Policy Pract. 2017, 37, 342-349. [CrossRef]

78. Statistique Canada. Montréal V [Subdivision de recensement], Québec et Montréal, TÉ [Division de recensement], Québec (tableau) In Ottawa; Statistique Canada: Ottawa, ON, Canada, 2017.

79. Tarasuk, V.; Mitchell, A.; Dachner, N. Household Food Insecurity in Canada, 2014; Research to Identify Policy Options to Reduce Food Insecurity (PROOF): Toronto, ON, Canada, 2016. 
80. Springmann, V.; Drouin, L.-R.F.C. La Santé des Montréalais: Les Maladies Chroniques et Leurs Déterminants Selon L'enquête Topo 2012; Direction de santé publique, Agence de la santé et des services sociaux de Montréal, Montréal: Montréal, QC, Canada, 2014.

81. Apparicio, P.; Cloutier, M.-S.; Shearmur, R. The case of Montreal's missing food deserts: Evaluation of accessibility to food supermarkets. Int. J. Health Geogr. 2007, 6, 4. [CrossRef]

82. Daniel, M.; Kestens, Y.; Paquet, C. Demographic and urban form correlates of healthful and unhealthful food availability in Montréal, Canada. Can. J. Public Health Rev. Can. Sante'e Publique 2009, 3, 189-193. [CrossRef]

83. Bertrand, L.; Thérien, F.; Cloutier, M.-S. Measuring and mapping disparities in access to fresh fruits and vegetables in Montreal. Can. J. Public Health Rev. Can. Sante'e Publique 2008, 1, 6-11. [CrossRef]

84. Bertrand, L.; Thérien, F.; Goudreau, S.; Fournier, M. Étude sur L'accès aux Aliments Santé à Montréal. Six ans Après la Première Etude, Mêmes Disparités? Agence de La Santé et des Services Sociaux de Montréal: Montréal, QC, Canada, 2013; p. 62.

85. Direction Régionale de Santé Publique du CIUSSS du Centre-Sud-de-l'Île-de-Montréal. Cadre de Référence Pour la Mesure 1.2 de Santé Publique. In Programme de Soutien à L'amélioration de L'accès Aux Fruits et Légumes à Montréal 2018-2021; Direction Régionale de Santé Publique du CIUSSS du Centre-Sud-de-l'Île-de-Montréal: Montréal, QC, Canada, 2018; p. 24.

86. Direction de Santé Publique de L'agence de La Sante et des Services Sociaux de Motnréal. Cadre de Référnce: Une Ville et des Quartiers Qui Favorisent L'accès Aux Aliments Santé et Leur Consommation. In Programme de Soutien aux Initiatives Locales 2013-2018; Direction de Santé Publique de L'agence de La Sante et des Services Sociaux de Motnréal: Montréal, QC, Canada, 2013; p. 28.

87. Direction de La Santé Publique de Montréal. Caractéristiques Sociodémographiques de la Population 2011; Direction de la Santé Publique de Montréal: Montréal, QC, Canada, 2011.

88. Statistique Canada Les Mesures de Faible Revenu. Available online: http://Www.Statcan.Gc.Ca/Pub/ 75f0002m/2012002/Lim-Mfr-Fra.Htm (accessed on 21 December 2019).

89. Bertrand, L.G.S. Étude sur L'accès aux Aliments Sains à Montreal: Regard Sur le Territoire du CSSS Lucille-Teasdale; Direction Régionale de Santé Publique du CIUSSS du Centre-Sud-de-l'Île-de-Montréal: Montréal, QC, Canada, 2014.

90. Y'a QuelQu'un de L'aut'bord du Mur. Rapport Annuel YYQ 2014; Y'a QuelQu'un de L'aut'bord du Mur: Montréal, QC, Canada, 2014; p. 64.

91. Y'a QuelQu'un de L'aut'bord du Mur. Rapport Annuel YYQ 2016; Y'a QuelQu'un de L'aut'bord du Mur: Montréal, QC, Canada, 2016; p. 43.

92. Chaput, S.; Mercille, G.; Drouin, L.; Kestens, Y. Promoting access to fresh fruits and vegetables through a local market intervention at a subway station. Public Health Nutr. 2018, 21, 3258-3270. [CrossRef] [PubMed]

93. Green, S.H.; Glanz, K. Development of the perceived nutrition environment measures survey. Am. J. Prev. Med. 2015, 49, 50-61. [CrossRef]

94. Cheng, R.; Mercille, G.; Hamelin, A.; Apparicio, P. Partnering with local organizations to measure food shopping practices and perceptions of food access of Montrealers. In Proceedings of the Food Environments in Canada: Symposium and Workshop, Saskatoon, SK, Canada, 21-23 May 2015.

95. Olsho, L.; Baronberg, S.; Abel, Y.; Austin, C.; Booker, C.; Greece, J.; Levin, J.; Staub-DeLong, L.; Walker, D.K.; Abrami, A.; et al. Health Bucks Evaluation Toolkit; CDC, Ed.; National Center for Chronic Disease Prevention and Health Promotion: Atlanta, GA, USA, 2012.

96. Statistique Canada. Enquête Sur la Santé des Collectivités Canadiennes (3226); Statistique Canada: Ottawa, ON, Canada, 2014.

97. Shatenstein, B.; Payette, H. Evaluation of the relative validity of the short diet questionnaire for assessing usual consumption frequencies of selected nutrients and foods. Nutrients 2015, 7, 6362-6374. [CrossRef] [PubMed]

98. CIUSSS du Centre-Est-de-l'Île-de-Montréal. Enquête TOPO 2012: Guide Méthodologique; CIUSSS du Centre-Est-de-l'Île-de-Montréal: Montréal, QC, Canada, 2015; p. 116.

99. Clary, C.M.; Ramos, Y.; Shareck, M.; Kestens, Y. Should we use absolute or relative measures when assessing foodscape exposure in relation to fruit and vegetable intake? Evidence from a wide-scale Canadian study. Prev. Med. 2015, 71, 83-87. [CrossRef] [PubMed]

100. Health Canada Canadian Nutrient File. Available online: https:/www.canada.ca/en/health-canada/services/foodnutrition/healthy-eating/nutrient-data/canadian-nutrient-file-about-us.html (accessed on 21 December 2019). 
101. Mack, J.; Tong, D. Characterizing the spatial and temporal patterns of farmers' market visits. Appl. Geogr. 2015, 63, 43-54. [CrossRef]

102. Garriguet, D. La Qualité de L'alimentation au Canada; 82-003-XPF; Statistique Canada: Ottawa, ON, Canada, 2009; p. 14.

103. Meshefedjian, G.A.; Leaune, V.; Simoneau, M.-È.; Drouin, M. Disparities in lifestyle habits and health related factors of montreal immigrants: Is immigration an important exposure variable in public health? J. Immigr. Minority Health 2014, 16, 790-797. [CrossRef]

104. Gouvernement du Québec Espace Montréalais D'infomation sur La Santé: Chiffres-clés. Available online: https://emis.santemontreal.qc.ca/outils/chiffres-cles/ (accessed on 21 December 2019).

105. Kiszko, K.; Cantor, J.; Abrams, C.; Ruddock, C.; Moltzen, K.; Devia, C.; McFarline, B.; Singh, H.; Elbel, B. Corner Store Purchases in a Low-Income Urban Community in NYC. J. Community Health 2015, 40, 1084-1090. [CrossRef]

(C) 2019 by the authors. Licensee MDPI, Basel, Switzerland. This article is an open access article distributed under the terms and conditions of the Creative Commons Attribution (CC BY) license (http://creativecommons.org/licenses/by/4.0/). 